
\title{
$\begin{array}{ll}\text { Research Square } & \begin{array}{l}\text { Preprints are preliminary reports that have not undergone peer review. } \\ \text { They should not be considered conclusive, used to inform clinical practice, } \\ \text { or referenced by the media as validated information. }\end{array}\end{array}$
}

\section{Allo-HSCT compared with immunosuppressive therapy for acquired aplastic anemia: Is superiority a one-sided understanding?}

\author{
Yangmin Zhu \\ Chinese Academy of Medical Sciences Institute of Hematology and Blood Diseases Hospital \\ Qingyan Gao \\ Chinese Academy of Medical Sciences Institute of Hematology and Blood Diseases Hospital \\ Jing Hu \\ Chinese Academy of Medical Sciences Institute of Hematology and Blood Diseases Hospital \\ Dongrui Guan \\ Chinese Academy of Medical Sciences Institute of Hematology and Blood Diseases Hospital \\ Xu Liu \\ Chinese Academy of Medical Sciences Institute of Hematology and Blood Diseases Hospital
}

Fengkui Zhang ( $\sim$ zhangfengkuixys@163.com)

Institute of Hematology and Blood Diseases Hospital, Chinese Academy of Medical Sciences and Peking Union Medical College

https://orcid.org/0000-0002-2797-1339

Research article

Keywords: Aplastic anemia and bone marrow failure, transplantation, red cell disorders

Posted Date: December 18th, 2019

DOI: https://doi.org/10.21203/rs.2.19154/v1

License: (c) (7) This work is licensed under a Creative Commons Attribution 4.0 International License. Read Full License

Version of Record: A version of this preprint was published on March 6th, 2020. See the published version at https://doi.org/10.1186/s12865-0200340-x. 


\section{Abstract}

Background: Allogeneic hematopoietic stem cell transplantation (allo-HSCT) and immunosuppressive therapy (IST) are two major competing treatment strategies for acquired aplastic anemia (AA). Whether allo-HSCT is superior to IST as a front-line treatment for patients with AA has been a subject of debate. To comprehensively compare the efficacy and safety of allo-HSCT with IST as a front-line treatment for patients with AA.

Methods: We searched the Medline, Embase, and Cochrane Registry of Controlled Trials databases from January 2000 to March 2019. Studies comparing allo-HSCT with IST as a first-line therapy for patients with AA were included.

Results: Fifteen studies including a total of 5336 patients were included in the meta-analysis. The pooled hazard ratio (HR) for overall survival (OS) was $0.4\left(95 \% \mathrm{Cl} 0.074-0.733, P=0.016, \mathrm{I}^{2}=58.8 \%\right)$ and the pooled $\mathrm{HR}$ for failure-free survival (FFS) was $1.962\left(95 \% \mathrm{Cl} 1.43-2.493, P=0.000, \mathrm{I}^{2}=\right.$ $0 \%$ ). The pooled relative risk (RR) for overall response rate (ORR) was 1.691 (95\% $\mathrm{Cl} 1.433-1.996, P=0.000, \mathrm{I}^{2}=11.6 \%$ ).

Conclusion: Although survival was significantly longer among AA patients undergoing first-line allo-HSCT compared to those undergoing first-line IST, the selection of initial treatment for patients with newly diagnosed AA still requires comprehensive evaluation of donor availability, patient age, expected quality of life, risk of disease relapse or clonal evolution after IST, and potential use of adjunctive eltrombopag.

\section{Background}

Acquired aplastic anemia (AA) is a rare hematologic disease characterized by a profound deficit of hematopoietic stem and progenitor cells, bone marrow hypocellularity, and peripheral blood pancytopenia. It mainly affects children, young adults, and those over 60 years of age. The estimated incidence of AA ranges from 0.7 to 4.1 per million people per year, and it appears to be two to three times higher in Asia than in Europe and North America $[1,2]$. Although the occurrence of AA can be partly explained by some drugs, chemicals, viruses, and other external factors, the majority of cases are idiopathic [3]. The underlying pathophysiology is thought to be an aberrant autoimmune reaction involving the T-cell-mediated destruction of hematopoietic cells [4]. Major signs and symptoms are infections, hemorrhage, and symptoms of anemia. Symptoms may be severe and life-threatening or minor enough to not require transfusion support. The survival rate for AA has markedly improved in the past four decades because of advances in hematopoietic stem cell transplantation (HSCT), immunosuppressive drugs, and supportive care.

According to the 2015 Guidelines for the Diagnosis and Management of AA (GDMAA) of the British Committee for Standards in Haematology (BCSH), first-line immunosuppressive therapy (IST) is a combination of antithymocyte globulin (ATG) and ciclosporin (CsA), indicated for nonsevere AA (NSAA) patients who are transfusion dependent, bleeding, encountering infections, or wish for improved quality of life; severe AA (SAA) or very severe AA (VSAA) patients in the absence of an HLA-matched sibling (MSD); or SAA/VSAA patients > 35-50 years of age [5]. Although IST is effective at ameliorating pancytopenia in a number of patients, it is not effective in all cases. In addition, it has been recognized that a subset of patients treated with IST develop clonal hematopoiesis or somatic mutations that lead to myelodysplastic syndrome (MDS) or acute myeloid leukemia (AML) [6]. Furthermore, the frequent recurrence of AA makes this treatment strategy a second choice behind HSCT from an HLA-matched family member.

The 2015 GDMAA recommends first-line allogeneic hematopoietic stem cell transplantation (allo-HSCT) from the bone marrow of an MSD for treating SAA in young and adult patients who have an MSD. Unrelated donor (URD) HSCT is indicated for SAA after failure to respond to at least one course of IST. Alternative donor HSCT using either cord blood (CB) or a haploidentical family donor (HID) may be considered for patients after failure to respond to IST and in the absence of a MSD or a suitably matched URD [5]. Although matched related donor (MRD) HSCT can be successfully performed after the failure of IST or after evolution to MDS/AML, overall survival is reduced when transplantation is used as secondline treatment [7]. Moreover, the outcomes after allo-HSCT from an URD have steadily improved over the past three decades. Recent data have revealed similar outcomes for upfront-unrelated and matched sibling HSCT for pediatric AA, which supports the recommendation for first-line treatment with an URD-HSCT for children who lack an MSD [8, 9]. In the past, alternative donor HSCT was another salvage choice for cure in patients with refractory AA after IST, but morbidity and mortality from graft failure and complications of graft-versus-host disease (GVHD) have limited clinical applications for this approach. With the improvements in transplantation technology and management of GVHD, haploidenticalHSCT (HID-HSCT) has become a viable alternative treatment for patients who lack an MRD. The successful application of posttransplant cyclophosphamide (PT-CY) for HLA-haploidentical grafts for AA patients generated high rates of engraftment, low rates of transplant-related mortality, low rates of GVHD, and eradication of pre-existing clonal diseases [10]. The evidence of improved long-term survival after HID-HSCT supports the potential role of HID-HSCT as a first-line therapy.

To compare the efficacy and safety of allo-HSCT with that of IST as a front-line treatment for patients with AA, we performed a meta-analysis of available studies that examined the impact of the two major competing treatment strategies for AA.

\section{Methods}

\section{Search strategy and study selection}


We searched the Medline, Embase, and Cochrane Registry of Controlled Trials databases from January 2000 to March 2019 . We also screened the reference lists of all identified studies and relevant articles including review papers. We used the following search terms: (Allogeneic hematopoietic stem cell transplantation OR Marrow transplantation) AND (Immunosuppressive therapy OR antithymocyte OR antilymphocyte globulin) AND (aplastic anemia). Studies comparing allo-HSCT with IST as a first-line therapy for patients with AA were included. Two reviewers (QYG and JH) independently screened the titles and abstracts of all identified studies to assess their eligibility for inclusion. Only studies with full-text and a sample size $>30$ patients were included.

\section{Data extraction and quality assessment}

Two reviewers (XL and YMZ) independently extracted the data from each study including first author, publication year, study region, period of enrollment, patient number, median age, conditioning program, hematopoietic source, prevention of GVHD, follow-up time, and study outcome. Disagreements between the two reviewers were resolved via discussion. Two researchers (QYG and DRG) assessed the quality of the included studies using the Newcastle-Ottawa Scale (NOS) [11]. The NOS consists of eight items classified into three dimensions including selection (four items), comparability (one item), and exposure (three items). A study can be awarded a maximum of one star for each item within the selection and exposure categories and a maximum of two stars can be given for comparability. The quality of the studies was classified into high quality (scores 7-9), intermediate quality (scores 4-6), and low quality (scores 1-3) studies.

\section{Definition of outcomes}

Primary outcomes of this study were overall survival (OS) and failure-free survival (FFS). Secondary outcomes were overall response rate (ORR), complete response rate (CR), treatment-related mortality (TRM), rates of engraftment, graft failure and GVHD, incidence of MDS/AML after IST, and cause of death. OS was defined as the time to death from any cause or at the last follow-up (censored). FFS was defined as survival with response or censored. Death, no response, disease progression, or relapse were considered treatment failures in patients who received IST. Death, primary or secondary graft failure, and relapse were considered treatment failure in patients who received transplantation. In the IST cohort, evaluation of hematologic response was performed at 6 months following IST. Complete response (CR) was defined as a neutrophil count of more than $1.5 \times$ $10^{9} / \mathrm{L}$, a hemoglobin level of more than $110 \mathrm{~g} / \mathrm{L}$, and a platelet count of more than $100 \times 10^{9} / \mathrm{L}$. Partial response (PR) was defined as a neutrophil count of more than $0.5 \times 10^{9} / \mathrm{L}$, a hemoglobin level of more than $80 \mathrm{~g} / \mathrm{L}$, a platelet count more than $20 \times 10^{9} / \mathrm{L}$, and no requirement of blood transfusion.

\section{Statistical analyses}

All statistical analyses were performed using Stata software (ver. 14.0, StataCorp, College Station, TX, USA). Descriptive statistics were presented as median and range for non-comparative data. We measured the hazard ratios (HRs) for OS and FFS and relative risk (RR) for other outcomes. The HR and their $95 \%$ confidence intervals (Cls) were estimated by the method created by Tierney et al. [12]. The statistical heterogeneity of the studies was assessed using the chi-square-based Q-test and quantified with the $\mathrm{I}^{2}$ statistic $\left(\mathrm{I}^{2}=0-25 \%\right.$, no heterogeneity; $\mathrm{I}^{2}=25-50 \%$, moderate heterogeneity; $I^{2}=50-75 \%$, large heterogeneity; $I^{2}=75-100 \%$, extreme heterogeneity). A fixed-effect model with the inverse variance approach was used to calculate estimates of the pooled HR or RR and their respective $95 \% \mathrm{Cls}$. In the situation of moderate or large heterogeneity $\left(\mathrm{I}^{2}=25-75 \%\right.$ or $P$-value $<0.1)$, a random-effects model using the DerSimonian and Laird method was utilized.

\section{Results}

\section{Included studies}

We acquired 880 citations from the electronic database and manual searches and 27 potentially relevant citations were retrieved as full-text or were identified for more detailed investigation (Fig. 1). Five reviews and three abstracts were excluded, two studies were excluded for insufficient patient number, and two were excluded for potentially repeated reports. Ultimately, 15 studies with 5336 patients met the predefined selection criteria (Table 1).

\section{Characteristics of the included studies}

All studies reported the outcomes of AA patients treated with first-line allo-HSCT or IST [13-27]. The allo-HSCT group was divided into two subgroups: BMT-MRD and BMT-MUD. In one study, the BMT-matched unrelated donor (MUD) subgroup was deleted for having an insufficient patient number $(n=5)$ [14]. The non-transplant group consisted of two subgroups, cyclosporin alone and androgen. In one study, the androgen subgroup was deleted for receiving non-IST treatment [17]. Those studies were published between 2000 and 2019 , and all were retrospective studies. The case collection period ranged from 1976 to 2016. Sample sizes ranged from 31 to 2479 (15 to 1567 in the allo-HSCT group and 16 to 912 in the IST group). The study population was children in 7 studies, adults in 3 studies, and both children and adults in 5 studies. Most studies included only SAA patients, but 3 studies included SAA, VSAA, and NSAA patients. The median age was 8-28 years in the allo-HSCT group and 655 years in the IST group. Only one study reported mean age, and one study only reported the median age of the allo-HSCT group. One study reported neither the median age nor the sex ratio. For the allo-HSCT group, the donor was an MRD in 9 studies, an HID in 3 studies, and an MUD in 
1 study. One study used mainly MRD donors together with mismatched related donor (MMRD) or MUD. Most of the studies adopted a cyclophosphamide-based regimen as a conditioning program. Prophylaxis against GVHD mainly consisted of CsA and methotrexate (MTX). Stem cell sources consisted of bone marrow (BM), peripheral blood stem cells (PBSCs), and a few patients with CB. The IST drugs mainly consisted of ATG or ALG combined with CsA. The quality of the studies in the analyses was high, with a mean overall NOS assessment score of 7.2 (range, 78).

\section{Primary outcomes}

All studies reported OS. The pooled HR for OS was 0.4 (95\% Cl $\left.0.074-0.733, P=0.016, \mathrm{I}^{2}=58.8 \%\right)$ (Fig. 2). These data indicate that first-line alloHSCT is significantly superior to IST for patients with AA. However, we found marked heterogeneity in the pooled HR for OS, and a subsequent sensitivity analysis revealed four studies had caused significant heterogeneity. After excluding these four studies [15, 18, 19, 25], the pooled HR for OS from the remaining 11 studies with 1875 patients was $0.955\left(95 \% \mathrm{Cl} 0.443-1.468, P=0.000, \mathrm{I}^{2}=34.7 \%\right)($ Fig. 3$)$, which still indicates the superiority of first-line allo-HSCT over IST for patients with AA. When OS was analyzed according to the publication year, there was a trend towards longer survival among patients undergoing first-line allo-HSCT compared to IST between 2010 and $2019(\mathrm{HR}=0.286,95 \% \mathrm{Cl}-0.008-0.58, P=$ $0.057, \mathrm{I}^{2}=0 \%$ ). Data analysis prior to 2010 was not performed due to the extreme heterogeneity of the results. When OS was analyzed according to the study population, there was a trend towards longer survival among adult patients undergoing first-line allo-HSCT compared to those undergoing IST ( $\left.\mathrm{HR}=0.801,95 \% \mathrm{Cl}-0.056-1.658, P=0.067, \mathrm{I}^{2}=0 \%\right)$. Although large heterogeneity was detected, first-line allo-HSCT was significantly superior to first-line IST for children with AA (HR $\left.=1.068,95 \% \mathrm{Cl} 0.358-1.779, P=0.003, I^{2}=54 \%\right)$. We then analyzed 0 S according to the disease severity, and there was significantly longer survival among SAA patients undergoing first-line allo-HSCT compared to first-line IST (HR = $0.506,95 \% \mathrm{Cl} 0.13-0.881, P=0.008, \mathrm{I}^{2}=38.8 \%$ ). We further analyzed OS according to the donor type and found no difference in survival between patients undergoing first-line haploidentical-HSCT and IST (HR =0.563, 95\% Cl -0.315-1.441, $P=0.209, \mathrm{I}^{2}=0 \%$ ). However, significantly longer survival with large heterogeneity was observed in patients undergoing first-line MRD-HSCT compared to IST $(\mathrm{HR}=0.711,95 \% \mathrm{Cl} 0.053-1.37, P=$ $\left.0.034,1^{2}=73.4 \%\right)$.

Five studies including 802 patients reported FFS in the meta-analysis. The pooled HR for FFS was $1.962\left(95 \% \mathrm{Cl} 1.43-2.493, P=0.000, \mathrm{I}^{2}=0 \%\right)$ (Fig. 4), which indicates that first-line allo-HSCT was significantly superior to IST for patients with AA in regard to FFS.

\section{Secondary outcomes}

Three studies including 314 patients reported comparable ORR in the meta-analysis. The pooled RR for ORR was 1.691 (95\% $\mathrm{Cl} 1.433-1.996, P=$ $\left.0.000, I^{2}=11.6 \%\right)$. These data indicate that first-line allo-HSCT caused a higher treatment response compared to first-line IST for patients with AA. Four studies reported comparable CRs but they were not included in the data analysis due to their extreme heterogeneity. Only two studies including 238 patients reported comparable TRM. There was a significantly higher TRM among patients undergoing first-line allo-HSCT compared to IST (pooled RR 3.98, 95\% Cl 1.911-8.29, $P=0.000, \mathrm{I}^{2}=0 \%$ ).

Ten studies including 3339 patients reported all-cause mortality. For these studies, the pooled RR was $0.851\left(95 \% \mathrm{Cl} 0.618-1.174, P=0.327, \mathrm{I}^{2}=\right.$ $57.1 \%$ ) (Fig. 5). No difference in all-cause mortality was observed between patients who received first-line allo-HSCT and those who received IST. Subsequent analysis revealed no difference in mortality resulting from hemorrhage (pooled $\mathrm{RR}=0.491,95 \% \mathrm{Cl} 0.199-1.208, P=0.122, \mathrm{I}^{2}=37 \%$ ) but there was significantly higher mortality resulting from infection among patients who received first-line IST compared to first-line allo-HSCT (pooled RR $=1.378,95 \% \mathrm{Cl} 1.081-1.757, P=0.01, \mathrm{I}^{2}=0 \%$ ). The median rate of engraftment was $96 \%$ (range $80-100 \%$ ) and the median rate of graft failure was $5 \%$ (range 1-13\%) for patients who received first-line allo-HSCT. Acute GVHD developed in $42.5 \%$ (range $23-100 \%$ ) of patients, $25 \%$ (range 4-48\%) of which were grade II-IV. Chronic GVHD developed in 30\% (range 7-61\%) of patients, 28\% (range 6-39\%) of patients had limited cGVHD, 6.5\% (range 3-30\%) of patients had extensive cGVHD, and 7\% (range 2-27\%) died of GVHD. Of the patients that received first-line IST, 4\% (range 1-19\%) developed MDS/AML and 15\% (range 9.5-45\%) experienced relapse. Only two studies reported the incidence of paroxysmal nocturnal hemoglobinuria (PNH) after first-line allo-HSCT or IST ( $6 \%$ and $12 \%$, respectively).

\section{Disscussion}

Acquired aplastic anemia (AA) is a serious hematologic disorder characterized by peripheral blood pancytopenia caused by bone marrow failure. The pathogenesis of this disease is thought to be the destruction of hematopoietic stem cells by autoimmunity. Allo-HSCT and IST using a combination of ATG and CsA have been the cornerstone of therapy for both SAA and NSAA patients since the 1970s. MRD-HSCT is now recommended as a first-line treatment for young and adult patients who have an MRD. MUD-HSCT is indicated for SAA patients after failure to respond to IST. First-line IST is a therapeutic option for patients in the absence of an MRD or with old age. However, this treatment approach is based on the results of comparative studies conducted mainly in the 1980s. Transplantation success for AA patients with an MRD has improved considerably over the past three decades, with a $75-80 \%$ chance of long-term cure. Now there is controversy concerning the upper age limit for MRD-HSCT as a first-line treatment because results vary in different series. Data from the European Group for Blood and Marrow Transplantation (EBMT) database revealed similar outcomes for patients in the age ranges of 20 to 30 years, 30 to 40 years, and 40 to 50 years [28]. Although 
treating a patient with transplantation alone in the case of IST failure is an appealing strategy, outcomes in patients undergoing transplantation after failing IST are worse than those in patients treated with first-line MRD-HSCT [7]. During the last two decades, the outcome of allo-HSCT for AA patients with an MUD has also improved significantly, suggesting that this treatment should be given an increased role in the treatment of children and young adults with AA who are without an MRD. Recent studies have revealed similar long-term OS after transplantation from an MRD compared to an MUD [8]. MUD-HSCT is therefore recommended as the first-line treatment for AA patients eligible for transplant but lacking an MRD. Furthermore, it may even be appropriate for some older adults to proceed with first-line MUD-HSCT. Alternative donor transplantation with PTCY for AA has shown satisfactory outcomes, with high rates of engraftment, low rates of transplant-related mortality, low rates of GVHD, and eradication of pre-existing clonal diseases [10]. This program allowed expansion of the donor pool to allow use of HIDs and MRDs, and it is also under development as a first-line therapy in appropriate patient circumstances. Altogether, the evidence for improved long-term survival after alloHSCT from various donor types supports the broader role of allo-HSCT as a first-line therapy. To comprehensively evaluate the efficacy and safety of allo-HSCT compared with IST as a front-line treatment for patients with AA, we performed a meta-analysis that examined the impact of the two major competing treatment strategies.

Our meta-analysis demonstrated significantly longer OS and FFS, as well as a higher response rate, for patients who underwent first-line allo-HSCT compared to first-line IST. However, this outcome should be interpreted with caution. All studies were non-randomized retrospective studies, and there was significant selection bias in the analysis. Young patients with severe disease and with available donors were more likely to receive transplantation, whereas older patients, patients with no available donor, or patients with severe complications tended to receive IST. Moreover, non-transplant centers would probably apply more likely IST while transplant centers would tend to apply allo-HSCT, which would add further bias. Most of the studies reported the outcomes of patients given first-line MRD-HSCT compared to those of patients given IST. Only two and three studies reported the outcomes of first-line MUD-HSCT and HID-HSCT compared to IST, respectively. Evidence for improved long-term survival with first-line allo-HSCT over IST is more robust for patients given first-line MRD-HSCT. Moreover, we found no difference in survival between patients undergoing first-line HID-HSCT and first-line IST in our subgroup analysis. This is consistent with the present controversial treatment situation. In China, HID-HSCT has been advocated as a first-line treatment for children with AA [21], but in the United States and Europe, HID-HSCT is regarded as an experimental treatment for the relatively limited number of cases reported with unknown long-term effects of complicated regimens and a mismatched immune system. In addition, we observed a great disparity in FFS for patients treated with allo-HSCT versus IST. Treatment failure was defined as death, no response, disease progression, or relapse in patients who received IST. However, the time of response evaluation was at 6 months after completion of treatment in most studies. In fact, the number of patients that achieved response increased over time for patients who received IST. Some patients acquired a defined response as late as 24 months after the completion of treatment [15]. In this situation, FFS may have been underestimated for patients who received IST. In addition, although overall survival was reduced when allo-HSCT was used as a secondline treatment compared to a first-line treatment in some studies, the survival advantage of allo-HSCT as a first-line treatment over allo-HSCT as a second-line treatment after the failure of IST or IST as a first-line treatment is still unknown.

Eltrombopag is an oral thrombopoietin receptor agonist used for patients who remain pancytopenic after initial treatment with IST. Recently, it was also under evaluation for use in combination with nontransplant IST for the treatment of SAA as a first-line therapy. In a recent study, the addition of eltrombopag to IST was associated with markedly higher rates of hematologic response among patients with SAA than in a historical cohort. The overall response rate at 6 months was $94 \%$ in one of three cohorts; at a median follow-up of 2 years, the survival rate was $97 \%$ [29]. However, to date, there has been no study comparing the efficacy of first-line allo-HSCT and first-line IST in combination with eltrombopag. In our opinion, this nontransplant combination therapy strategy may counterbalance the survival advantage of allo-HSCT in indicated patients with AA.

Based on recent data, some investigators have recommended revision of the guidelines for the initial treatment of patients with newly diagnosed SAA. Allo-HSCT should be considered as a first-line treatment for patients with newly diagnosed SAA. At the time of diagnosis, HLA typing should be performed to identify a marrow donor among family members or in the unrelated donor registries. The priority order of donor source for HSCT is: (1) MRD, (2) MUD, and (3) HID if a MUD is not rapidly available. Each of these donor marrow sources may be preferable to IST because of the long-term persistent risk for disease relapse and secondary MDS/AML with the use of nontransplant IST for patients with AA. In contrast, alloHSCT is associated with high cure rate, a relatively low risk for GVHD, and a low risk for disease relapse or the development of clonal disorders [30]. It has been well recognized that a high incidence of mutations that lead to the emergence of clonal evolution and MDS/AML can be detected after IST treatment. However, it should be noted that evidence of clonal hematopoiesis resulting from bone marrow failure does not reliably predict the development of clinically diagnosed diseases. In one study, only a small minority of AA patients with ASXL1 or DNMT3A mutations developed MDS during the follow-up period [31]. This is consistent with what was found during our meta-analysis. We found that a median of $15 \%$ (9.5-45\%) of patients in our included studies experienced relapse, which is lower than the $37-38 \%$ of patients reported in other studies [32, 33]. This discrepancy may be due to different patient populations, the definition of response, treatment protocols, and the limited follow-up time in some studies. It has been suggested that IST should not be discontinued after response to therapy in patients with NSAA and SAA due to the high risk of relapse. Indefinite administration of low dose CsA may reduce the incidence of relapse [34]. For patients who received allo-HSCT, we found a higher incidence of GVHD, but the incidence of grade II-IV aGVHD, extensive cGVHD, and death caused by GVHD was relatively low.

Given that we saw no difference in all-cause mortality between patients who received allo-HSCT and IST, the quality of life assessment is a matter of cardinal significance for comparing these two treatment strategies. The late clinical effects of allo-HSCT are of major concern for patients who

Page 5/15 
survive long-term after transplantation, but they are often left out of the comparison of the two treatment strategies. For example, fertility has been shown to be reduced when alkylating agents are combined with irradiation during pretransplant conditioning. Children born to patients who recover gonadal function and fertility after transplantation are at increased risk for developing genetic diseases and congenital anomalies [35]. The qualityadjusted time without symptoms and toxicity (Q-TWiST) analysis is a methodology that allows for retrospectively evaluating the time a patient spent in different health states, assuming that quality of life is dependent on each particular health state [36]. This methodology can provide a comprehensive view on the outcome of the two treatment modalities by integrating quality of life considerations into the comparison, such as treatment toxicity, transfusion necessity, drug requirements, GVHD, or clonal evolution. Studies that used Q-TWiST revealed that patients treated with allo-HSCT spend more time cured from their disease, whereas IST patients have greater requirements for close medical care, transfusion support, medication requirements, and spend more time in cost-intensive intervals, although similar survival and event-free survival were observed [18].

\section{Conclusions}

Although survival is significantly longer among AA patients undergoing first-line allo-HSCT compared to first-line IST, the selection of initial treatment for patients with newly diagnosed AA requires a comprehensive evaluation of donor availability, age, expected quality of life, risk of disease relapse or clonal evolution after IST, and the use of adjunctive eltrombopag. Our meta-analysis highlights the need for prospective studies to examine the role of these two treatment modalities.

\section{Declarations}

\section{Acknowledgments}

We sincerely thank all patients and clinical investigators who were involved in the studies selected for this meta-analysis.

\section{Author details}

Department of Therapeutic Center of Anemia, Institute of Hematology and Blood Diseases Hospital, Chinese Academy of Medical Science \& Peking Union Medical College (CAMS \& PUMC), Tianjin, China

\section{Authors' contributions}

YMZ and LX carried out the publication search, participated in data collecting and analysis, and drafted the manuscript. JH and XL participated in the publication search and helped to draft the manuscript. QYG participated performed the statistical analysis. FKZ revised the manuscript. All authors read and approved the final manuscript.

\section{Competing interests}

The authors declare that they have no competing interests.

\section{Abbreviations}

AA: Aplastic anemia; allo-HSCT: Allogeneic hematopoietic stem cell transplantation; IST: Immunosuppressive therapy; MSD: HLA-matched sibling; URD: Unrelated donor; HID: Haploidentical family donor; GVHD: Graft-versus-host disease.

\section{References}

1. S Kojima: Why is the incidence of aplastic anemia higher in Asia? Expert Rev Hematol 2017, 10:277-279.

2. DW Kaufman, JP Kelly, S Issaragrisil, JR Laporte, T Anderson, M Levy, S Shapiro, NS Young: Relative incidence of agranulocytosis and aplastic anemia. Am J Hematol 2006, 81:65-7.

3. NS Young: Acquired aplastic anemia. Ann Intern Med 2002, 136:534-46.

4. NS Young, J Maciejewski: The pathophysiology of acquired aplastic anemia. N Engl J Med 1997, 336:1365-72.

5. SB Killick, N Bown, J Cavenagh, I Dokal, T Foukaneli, A Hill, P Hillmen, R Ireland, A Kulasekararaj, G Mufti, et al: Guidelines for the diagnosis and management of adult aplastic anaemia. Br J Haematol 2016, 172:187-207.

6. AG Kulasekararaj, J Jiang, AE Smith, AM Mohamedali, S Mian, S Gandhi, J Gaken, B Czepulkowski, JC Marsh, GJ Mufti: Somatic mutations identify a subgroup of aplastic anemia patients who progress to myelodysplastic syndrome. Blood 2014, 124:2698-704.

7. L Ades, JY Mary, M Robin, C Ferry, R Porcher, H Esperou, P Ribaud, A Devergie, R Traineau, E Gluckman, et al: Long-term outcome after bone marrow transplantation for severe aplastic anemia. Blood 2004, 103:2490-7. 
8. BK Mortensen, N Jacobsen, C Heilmann, H Sengelov: Allogeneic hematopoietic cell transplantation for severe aplastic anemia: similar longterm overall survival after transplantation with related donors compared to unrelated donors. Bone Marrow Transplant 2016, 51:288-90.

9. C Dufour, P Veys, E Carraro, N Bhatnagar, M Pillon, R Wynn, B Gibson, AJ Vora, CG Steward, AM Ewins, et al: Similar outcome of upfrontunrelated and matched sibling stem cell transplantation in idiopathic paediatric aplastic anaemia. A study on behalf of the UK Paediatric BMT Working Party, Paediatric Diseases Working Party and Severe Aplastic Anaemia Working Party of EBMT. Br J Haemato/ $2015,171: 585-94$.

10. AE DeZern, M Zahurak, H Symons, K Cooke, RJ Jones, RA Brodsky: Alternative Donor Transplantation with High-Dose Post-Transplantation Cyclophosphamide for Refractory Severe Aplastic Anemia. Biol Blood Marrow Transplant 2017, 23:498-504.

11. JF Tierney, LA Stewart, D Ghersi, S Burdett, MR Sydes: The Newcastle-Ottawa Scale (NOS) for assessing the quality of nonrandomised studies in meta-analyses. Available from: http://www.ohri.ca/programs/clinical_epidemiology/oxford.asp.

12. JF Tierney, LA Stewart, D Ghersi, S Burdett, MR Sydes: Practical methods for incorporating summary time-to-event data into meta-analysis. Trials 2007, 8:16.

13. S Kojima, K Horibe, J Inaba, A Yoshimi, Y Takahashi, K Kudo, K Kato, $T$ Matsuyama: Long-term outcome of acquired aplastic anaemia in children: comparison between immunosuppressive therapy and bone marrow transplantation. Br J Haematol 2000, 111:321-8.

14. M Fouladi, R Herman, M Rolland-Grinton, D Jones-Wallace, V Blanchette, S Calderwood, J Doyle, D Halperin, M Leaker, EF Saunders, et al: Improved survival in severe acquired aplastic anemia of childhood. Bone Marrow Transplant 2000, 26:1149-56.

15. RJ Ellis, Q Kahn, BS Skikne, MS Mayo, JW Allgood, DM Bodensteiner, D Deauna-Limayo, JD Cook: A retrospective analysis of long-term survival in severe aplastic anemia patients treated with allogeneic bone marrow transplantation or immunosuppressive therapy with antithymocyte globulin and cyclosporin A at a single institution. Mil Med 2002, 167:541-5.

16. I Kim, SS Yoon, S Park, BK Kim, NK Kim: The treatment of severe aplastic anemia: outcomes of bone marrow transplantation and immunosuppressive therapy in a single institution of Korea. J Korean Med Sci 2003, 18:365-71.

17. A Ghavamzadeh, $M$ Iravani, $F$ Vafaiezadeh, $M$ Jahani, A Mousavi: Bone marrow transplantation versus immunosuppressive therapy in severe aplastic anemia, 1990 - 2001. Arch Iranian Med 2004, 7:272-278.

18. R Viollier, J Passweg, M Gregor, G Favre, T Kuhne, C Nissen, A Gratwohl, A Tichelli: Quality-adjusted survival analysis shows differences in outcome after immunosuppression or bone marrow transplantation in aplastic anemia. Ann Hemato/ 2005, 84:47-55.

19. A Locasciulli, R Oneto, A Bacigalupo, G Socie, E Korthof, A Bekassy, H Schrezenmeier, J Passweg, M Fuhrer: Outcome of patients with acquired aplastic anemia given first line bone marrow transplantation or immunosuppressive treatment in the last decade: a report from the European Group for Blood and Marrow Transplantation (EBMT). Haematologica 2007, 92:11-8.

20. YB Choi, ES Yi, JW Lee, KW Sung, HH Koo, KH Yoo: Immunosuppressive therapy versus alternative donor hematopoietic stem cell transplantation for children with severe aplastic anemia who lack an HLA-matched familial donor. Bone Marrow Transplant 2017, 52:47-52.

21. Y Cheng, Z Xu, Y Zhang, J Wu, F Wang, X Mo, Y Chen, W Han, J Jia, Y Wang, et al: First-line choice for severe aplastic anemia in children: Transplantation from a haploidentical donor vs immunosuppressive therapy. Clin Transplant 2018, 32.

22. ZL Xu, M Zhou, JS Jia, WJ Mo, XH Zhang, YP Zhang, Y Wang, YM Li, XJ Huang, SQ Wang, et al: Immunosuppressive therapy versus haploidentical transplantation in adults with acquired severe aplastic anemia. Bone Marrow Transplant 2019.

23. MJ Ahn, JH Choi, YY Lee, IY Choi, IS Kim, SS Yoon, SY Park, BK Kim, C Suh, HJ Son, et al: Outcome of adult severe or very severe aplastic anemia treated with immunosuppressive therapy compared with bone marrow transplantation: multicenter trial. Int $\mathrm{J}$ Hemato/ 2003, 78:133-8.

24. N Yoshida, R Kobayashi, H Yabe, Y Kosaka, H Yagasaki, K Watanabe, K Kudo, A Morimoto, S Ohga, H Muramatsu, et al: First-line treatment for severe aplastic anemia in children: bone marrow transplantation from a matched family donor versus immunosuppressive therapy. Haematologica 2014, 99:1784-91.

25. B George, V Mathews, A Viswabandya, A Abraham, A Ganapule, NA Fouzia, A Korula, KN Lakshmi, M Chandy, A Srivastava: Immunosuppressive Therapy and Bone Marrow Transplantation for Aplastic Anaemia-The CMC Experience. J Assoc Physicians India 2015, 63:36-40.

26. C Dufour, M Pillon, G Socie, A Rovo, E Carraro, A Bacigalupo, R Oneto, J Passweg, A Risitano, A Tichelli, et al: Outcome of aplastic anaemia in children. A study by the severe aplastic anaemia and paediatric disease working parties of the European group blood and bone marrow transplant. Br J Haematol 2015, 169:565-73.

27. S Yang, X Yuan, R Ma, L Jiang, J Guo, Y Zang, J Shi, J Yang, P Lei, Z Liu, et al: Comparison of Outcomes of Frontline Immunosuppressive Therapy and Frontline Haploidentical Hematopoietic Stem Cell Transplantation for Children with Severe Aplastic Anemia Who Lack an HLAMatched Sibling Donor. Biol Blood Marrow Transplant 2019, 25:975-980.

28. JR Passweg, JC Marsh: Aplastic anemia: first-line treatment by immunosuppression and sibling marrow transplantation. Hematology Am SoC Hematol Educ Program 2010, 2010:36-42.

29. DM Townsley, P Scheinberg, T Winkler, R Desmond, B Dumitriu, O Rios, B Weinstein, J Valdez, J Lotter, X Feng, et al: Eltrombopag Added to Standard Immunosuppression for Aplastic Anemia. N Engl J Med 2017, 376:1540-1550. 
30. GE Georges, K Doney, R Storb: Severe aplastic anemia: allogeneic bone marrow transplantation as first-line treatment. Blood Adv 2018, 2:20202028.

31. T Yoshizato, B Dumitriu, K Hosokawa, H Makishima, K Yoshida, D Townsley, A Sato-Otsubo, Y Sato, D Liu, H Suzuki, et al: Somatic Mutations and Clonal Hematopoiesis in Aplastic Anemia. N Engl J Med 2015, 373:35-47.

32. P Scheinberg, O Nunez, C Wu, NS Young: Treatment of severe aplastic anaemia with combined immunosuppression: anti-thymocyte globulin, ciclosporin and mycophenolate mofetil. Br J Haematol 2006, 133:606-11.

33. N Frickhofen, H Heimpel, JP Kaltwasser, H Schrezenmeier: Antithymocyte globulin with or without cyclosporin A: 11-year follow-up of a randomized trial comparing treatments of aplastic anemia. Blood 2003, 101:1236-42.

34. H Jalaeikhoo, A Khajeh-Mehrizi: Immunosuppressive therapy in patients with aplastic anemia: a single-center retrospective study. Plos One 2015, 10:e0126925.

35. JE Sanders, J Hawley, W Levy, T Gooley, CD Buckner, HJ Deeg, K Doney, R Storb, K Sullivan, R Witherspoon, et al: Pregnancies following highdose cyclophosphamide with or without high-dose busulfan or total-body irradiation and bone marrow transplantation. Blood 1996, 87:304552.

36. RD Gelber, BF Cole, A Goldhirsch, G Bonadonna, A Howell, CS McArdle, HT Mouridsen, RD Rubens, K Welvaart: Adjuvant chemotherapy for premenopausal breast cancer: a meta-analysis using quality-adjusted survival. Cancer J Sci Am 1995, 1:114-21.

\section{Table}

Table 1 Characteristics and quality assessment of individual studies included in the meta-analysis 


\begin{tabular}{|c|c|c|c|c|c|c|c|c|c|c|c|c|c|}
\hline $\begin{array}{l}\text { First author } \\
\text { (Publication } \\
\text { year) }\end{array}$ & $\begin{array}{l}\text { Duration } \\
\text { of study }\end{array}$ & Population & $\begin{array}{l}\text { Disease } \\
\text { severity }\end{array}$ & $\begin{array}{l}\text { Median age } \\
\text { (HSCT/IST) }\end{array}$ & $\begin{array}{l}\text { Number of } \\
\text { patients } \\
\text { (HSCT/IST) }\end{array}$ & Donor & $\begin{array}{l}\text { Stem cell } \\
\text { source }\end{array}$ & $\begin{array}{l}\text { Conditioning } \\
\text { program }\end{array}$ & $\begin{array}{l}\text { Prevention } \\
\text { of GVHD }\end{array}$ & IST drugs & $\begin{array}{l}\text { Follow-up } \\
\text { time } \\
\text { (HSCT/IST) }\end{array}$ & $\begin{array}{l}\text { Selection } \\
\text { /Comparability } \\
\text { /Exposure }\end{array}$ & $\begin{array}{l}\text { Nos } \\
\text { Score }\end{array}$ \\
\hline $\begin{array}{l}\text { Kojima et al } \\
\text { (2000) }\end{array}$ & $\begin{array}{l}1984- \\
1998\end{array}$ & Children & $\begin{array}{l}\text { SAA + } \\
\text { VSAA + } \\
\text { NSAA }\end{array}$ & $\begin{array}{l}10(0-16) \\
9(1-17)\end{array}$ & $37 / 63$ & MRD & $\mathrm{BM}$ & $\begin{array}{l}\mathrm{Cy}+\mathrm{TLI}, \\
\mathrm{Cy}+\mathrm{ATG} \pm \\
\mathrm{TLI}, \\
\mathrm{Cy}+\mathrm{TLI}+ \\
\text { TBI }\end{array}$ & $\begin{array}{l}\text { MTX + } \\
\text { CsA, CsA }\end{array}$ & $\begin{array}{l}\text { ATG/ALG } \\
+ \\
\text { HD- } \\
\text { Steroids, } \\
\text { ATG + } \\
\text { CsA }\end{array}$ & $\begin{array}{l}89 \text { (6-166), } \\
82 \text { (6-186); } \\
\text { (Month) }\end{array}$ & $* * * * / * * / * *$ & 8 \\
\hline $\begin{array}{l}\text { Fouladi et al } \\
(2000)\end{array}$ & $\begin{array}{l}1987- \\
1997\end{array}$ & Children & SAA & $\begin{array}{l}8.8(2.1- \\
15.9), 9.8 \\
(1.3-16.6)\end{array}$ & $21 / 20$ & MRD & BM & $\begin{array}{l}\text { Cy + TBI } \\
\text { and others }\end{array}$ & $\begin{array}{l}\text { MTX + } \\
\text { CsA, CsA, } \\
\text { CsA + } \\
\text { Pred }\end{array}$ & $\begin{array}{l}\text { ATG } \pm \\
\text { CsA }\end{array}$ & $\begin{array}{l}4.3 \text { (3.3-6.7), } \\
3 \text { (0.2-6.7); } \\
\text { (Year) }\end{array}$ & $* * * / * * / * *$ & 7 \\
\hline $\begin{array}{l}\text { Ellis et al } \\
\text { (2002) }\end{array}$ & $\begin{array}{l}1977- \\
1999\end{array}$ & $\begin{array}{l}\text { Adult + } \\
\text { Children }\end{array}$ & SAA & $\begin{array}{l}22 \text { (6-59), } \\
55 \text { (9-78) }\end{array}$ & $15 / 16$ & MRD & $\mathrm{BM}$ & $\begin{array}{l}\mathrm{Cy} \pm \\
\text { Irradiation }\end{array}$ & $\begin{array}{l}\text { MTX } ₫ \mathrm{MTX} \\
+\mathrm{CsA}\end{array}$ & $\begin{array}{l}\text { ATG, } \\
\text { ATG + } \\
\text { CsA }\end{array}$ & $\begin{array}{l}4.3 \text { (0.2- } \\
242.2), 52.5 \\
(1.1-165.4) ; \\
\text { (Month) }\end{array}$ & $* * *|* *| * *$ & 7 \\
\hline $\begin{array}{l}\text { Kim et al } \\
\text { (2003) }\end{array}$ & $\begin{array}{l}1990- \\
1999\end{array}$ & Adult & SAA & $\begin{array}{l}22(14-43), \\
34(15-75)\end{array}$ & $22 / 74$ & MRD & $\mathrm{BM}$ & $\begin{array}{l}\text { Cy + TBI, } \\
\text { Cy + ATG, } \\
\mathrm{Bu}+\mathrm{Cy}\end{array}$ & $\begin{array}{l}\text { MTX + } \\
\text { CsA }\end{array}$ & $\begin{array}{l}\text { ATG/ALG, } \\
\text { ATG + } \\
\text { CsA }\end{array}$ & NR & $* * * \mid * * / * *$ & 7 \\
\hline $\begin{array}{l}\text { Ghavamzadeh } \\
\text { et al } \\
\text { (2004) }\end{array}$ & $\begin{array}{l}1990- \\
2001\end{array}$ & $\begin{array}{l}\text { Adult + } \\
\text { Children }\end{array}$ & SAA & $\begin{array}{l}19,25 \\
\text { (Mean) }\end{array}$ & $29 / 24$ & MRD & $\mathrm{BM} / \mathrm{PBSCs}$ & $\mathrm{CY} \pm \mathrm{ALG}$ & CsA & $\begin{array}{l}\mathrm{CsA} \pm \\
\mathrm{ALG}\end{array}$ & $\begin{array}{l}878 \text { (24- } \\
\text { 2750), } 403 \\
\text { (NR); } \\
\text { (Mean) } \\
\text { (Day) }\end{array}$ & $* * *|* *| * *$ & 7 \\
\hline $\begin{array}{l}\text { Viollier et al } \\
\text { (2005) }\end{array}$ & $\begin{array}{l}1976- \\
1999\end{array}$ & $\begin{array}{l}\text { Adult + } \\
\text { Children }\end{array}$ & $\begin{array}{l}\text { SAA + } \\
\text { VSAA + } \\
\text { NSAA }\end{array}$ & $\begin{array}{l}19(2-55), \\
23(2-74)\end{array}$ & $52 / 155$ & MRD & BM/PBSCs & $\mathrm{CY} \pm \mathrm{ATG}$ & $\begin{array}{l}\text { MTX } \triangle \mathrm{MTX} \\
+\mathrm{CsA}\end{array}$ & $\begin{array}{l}\text { ATG, ATG } \\
+ \text { CsA }\end{array}$ & $\begin{array}{l}11.5(2-22), \\
11.3 \text { (0.2- } \\
22) ;(\text { Year) }\end{array}$ & $* * * * / * * / * *$ & 8 \\
\hline $\begin{array}{l}\text { Loc asciulli } \\
\text { et al } \\
\text { (2007) }\end{array}$ & $\begin{array}{l}1991- \\
2002\end{array}$ & $\begin{array}{l}\text { Adult + } \\
\text { Children }\end{array}$ & SAA & $\begin{array}{l}18.7(1-67) \\
23.5(1-94)\end{array}$ & $1567 / 912$ & $\begin{array}{l}\text { MRD (85\%) } \\
+ \\
\text { MMRD } \\
(3 \%)+ \\
\text { MUD (10\%) }\end{array}$ & BM & $\begin{array}{l}\mathrm{Cy}, \mathrm{Cy}+ \\
\mathrm{ALG}, \\
\mathrm{Cy}+ \\
\text { Irradiation } \\
\text { (TBI, TLI, } \\
\text { TAI) }\end{array}$ & $\begin{array}{l}\text { CsA } \pm \\
\text { MTX, } \\
\text { some not } \\
\text { specified }\end{array}$ & $\begin{array}{l}\mathrm{ALG}+ \\
\mathrm{CsA} \pm \\
\text { G-CSF }\end{array}$ & $\begin{array}{l}41 \text { (24-155), } \\
54.4 \text { (14- } \\
144) \\
\text { (For alive) } \\
\text { (Month) }\end{array}$ & $* * * / * * / * *$ & 7 \\
\hline $\begin{array}{l}\text { Choi et al } \\
\text { (2017) }\end{array}$ & $\begin{array}{l}1998- \\
2012\end{array}$ & Children & SAA & $\begin{array}{l}9.3(0.6- \\
17.2), 8.5 \\
(1.3-14.1)\end{array}$ & $23 / 19$ & MUD & BM/PBSCs/CB & $\begin{array}{l}\text { Flu }+\mathrm{Cy} \pm \\
\text { TBI, } \\
\mathrm{Bu}+\mathrm{Cy}+ \\
\mathrm{ATG}, \\
\mathrm{Cy}+\mathrm{TBI}, \\
\mathrm{Cy}+\mathrm{ATG}\end{array}$ & $\begin{array}{l}\text { MTX + } \\
\text { CsA or } \\
\text { Tac, CsA, } \\
\text { others }\end{array}$ & $\begin{array}{l}\mathrm{ATG}+ \\
\mathrm{CsA}\end{array}$ & NR & $* * *|* *| * *$ & 7 \\
\hline $\begin{array}{l}\text { Cheng et al } \\
\text { (2017) }\end{array}$ & $\begin{array}{l}2007- \\
2016\end{array}$ & Children & SAA & $\begin{array}{l}8(2-17), \\
6(4-16)\end{array}$ & $28 / 24$ & HID & $\mathrm{BM}+\mathrm{PBSCs}$ & $\begin{array}{l}\mathrm{Bu}+\mathrm{Cy}+ \\
\mathrm{ATG}\end{array}$ & $\begin{array}{l}\text { CSA + } \\
\text { MTX + } \\
\text { MMF }\end{array}$ & $\begin{array}{l}\text { ATG + } \\
\text { CsA }\end{array}$ & $\begin{array}{l}37.9 \text { (8.7- } \\
108.3), 54.8 \\
\text { (8.9-115.7); } \\
\text { (Month) }\end{array}$ & $* * *|* *| * *$ & 7 \\
\hline $\begin{array}{l}\text { Xu et al } \\
\text { (2018) }\end{array}$ & $\begin{array}{l}2009- \\
2017\end{array}$ & Adult & SAA & $\begin{array}{l}28(18-49), \\
32(18-62)\end{array}$ & $28 / 32$ & HID & $\mathrm{BM}+\mathrm{PBSCs}$ & $\begin{array}{l}\mathrm{Bu}+\mathrm{Cy}+ \\
\mathrm{ATG}\end{array}$ & $\begin{array}{l}\text { MTX + } \\
\text { CsA + } \\
\text { MMF }\end{array}$ & $\begin{array}{l}\mathrm{ATG}+ \\
\mathrm{CsA}\end{array}$ & $\begin{array}{l}24.7 \text { (6.1- } \\
\text { 103), 20.2 } \\
\text { (3.2 -96.0); } \\
\text { (For alive) } \\
\text { (Month) }\end{array}$ & $* * * / * * \mid * *$ & 7 \\
\hline
\end{tabular}




\begin{tabular}{|c|c|c|c|c|c|c|c|c|c|c|c|c|c|}
\hline $\begin{array}{l}\text { Ahn et al } \\
\text { (2003) }\end{array}$ & $\begin{array}{l}1990- \\
2001\end{array}$ & Adult & SAA & $\begin{array}{l}28 \text { (14-43), } \\
\text { NR }\end{array}$ & $64 / 156$ & MRD & BM & $\begin{array}{l}C y+A T G \\
C y+T L I\end{array}$ & $\begin{array}{l}\mathrm{MTX}+ \\
\mathrm{CsA}, \mathrm{CsA}\end{array}$ & $\begin{array}{l}\text { ATG + } \\
\text { CsA, ATG } \\
+ \\
\text { HD- } \\
\text { Steroids, } \\
\text { CsA }\end{array}$ & NR & $* * * / * * / * *$ & 7 \\
\hline $\begin{array}{l}\text { Yoshida et al } \\
(2014)\end{array}$ & \begin{tabular}{|l|}
$1992-$ \\
2009
\end{tabular} & Children & SAA & $\begin{array}{l}11(0-16), \\
9(0-16)\end{array}$ & $213 / 386$ & MRD & BM & $\begin{array}{l}\mathrm{Cy} \pm \\
\text { Irradiation, } \\
\mathrm{CY}+\mathrm{ATG} \pm \\
\text { Irradiation, } \\
\text { Flu + Cy } \pm \\
\text { Irradiation, } \\
\text { Flu + Cy + } \\
\text { ATG } \pm \\
\text { Irradiation } \\
\text { and others }\end{array}$ & $\begin{array}{l}\text { MTX + } \\
\text { CsA or } \\
\text { Tac }\end{array}$ & $\begin{array}{l}\text { ATG }+ \\
\text { CsA } \pm \\
\text { G-CSF }\end{array}$ & \begin{tabular}{|l}
101 (18- \\
213), 106 \\
$(22-224) ;$ \\
(Month)
\end{tabular} & ***/**/** & 7 \\
\hline $\begin{array}{l}\text { George et al } \\
\text { (2015) }\end{array}$ & \begin{tabular}{|l|}
$1985-$ \\
2013
\end{tabular} & $\begin{array}{l}\text { Adult + } \\
\text { Children }\end{array}$ & $\begin{array}{l}\text { SAA + } \\
\text { VSAA + } \\
\text { NSAA }\end{array}$ & $\begin{array}{l}22(3-57) \\
30.1(1.5-74)\end{array}$ & $214 / 530$ & $\begin{array}{l}\text { MRD + } \\
\text { MMRD } \\
\text { (Percentage } \\
\text { NR) }\end{array}$ & $\mathrm{BM} / \mathrm{PBSCs}$ & $\begin{array}{l}\mathrm{Flu}+\mathrm{Cy}, \\
\mathrm{Cy} \pm \mathrm{ATG}, \\
\mathrm{Flu}+\mathrm{Bu} \\
\text { and others }\end{array}$ & $\begin{array}{l}\text { MTX + } \\
\text { CsA, } \\
\text { PT-CY }\end{array}$ & $\begin{array}{l}\text { ATG/ALG } \\
+ \\
\text { CsA }\end{array}$ & $\begin{array}{l}36 \text { (6-197), } \\
38 \text { (1-84); } \\
\text { (Month) }\end{array}$ & $* * * * / * * / * *$ & 8 \\
\hline $\begin{array}{l}\text { Dufour et al } \\
\text { (2015) }\end{array}$ & $\begin{array}{l}2000- \\
2009\end{array}$ & Children & SAA & NR & $396 / 167$ & MRD & $\mathrm{BM} / \mathrm{PBSCs}$ & $\begin{array}{l}\text { Сy, Сy + } \\
\text { Flu } \pm \text { ATG } \\
\text { and others }\end{array}$ & $\begin{array}{l}\text { CsA + } \\
\text { MTX }\end{array}$ & $\begin{array}{l}\text { ATG + } \\
\text { CsA }\end{array}$ & NR & $* * * / * * / * *$ & 7 \\
\hline $\begin{array}{l}\text { Yang et al } \\
\text { (2019) }\end{array}$ & \begin{tabular}{|l}
$2012-$ \\
2016
\end{tabular} & Children & SAA & $\begin{array}{l}13(4-18), \\
12(4-17)\end{array}$ & $20 / 29$ & HID & $\begin{array}{l}\text { BM/PBSCs, } \\
\text { BM+PBSCs }\end{array}$ & $\begin{array}{l}\mathrm{Cy}+\mathrm{ATG} \pm \\
\mathrm{Flu}, \\
\mathrm{Flu}+\mathrm{Cy}+ \\
\mathrm{Bu}+\mathrm{ATG}\end{array}$ & $\begin{array}{l}\mathrm{CsA}+ \\
\mathrm{MTX}+ \\
\mathrm{MMF}\end{array}$ & $\begin{array}{l}\text { ATG + } \\
\text { CsA }\end{array}$ & NR & $* * * / * * / * *$ & 7 \\
\hline
\end{tabular}

MMRD, Mismatchea related donor; Cy, Cyclophosphamide; Bu, Busulfan; TLI, Total lymphoid irradiation; TBI, Total body irradiation; TAI, Thoraco-abdominal irradiation; CsA, Cyclosporin A; G-CSF, Granulocyte colony-stimulating factor; Pred, Prednisone; Tac, Tacrolimus; MMF, Mycophenolate mofetil; HD-Steroids, High-dose steroids; NR, Not reported.

\section{Figures}


880 Citations were screened via the search strategy

853 Citations were excluded for irrelevant issues

27 Relevant citations were retrieved as full-text

or identified for more detailed information

5 Reviews were excluded

3 Abstracts were excluded

2 Potential repeated report were excluded

2 Excluded for an insufficient number of cases

15 Studies were identified for meta-analysis

Figure 1 
Study

ID
$\%$

$\operatorname{LogHR}(95 \% \mathrm{CI}) \quad$ Weight
Kojima (2000)

Fouladi (2000)

Ellis (2002)

Kim (2003)

Ahn (2003)

Ghavamzadeh (2004)

Viollier (2005)

Locasciulli (2007)

Yoshida (2014)

George (2015)

Dufour (2015)

Choi (2017)

Cheng (2017)

$\mathrm{Xu}(2018)$

Yang (2019)

Overall (I-squared $=58.8 \%, \mathrm{p}=0.002)$

NOTE: Weights are from random effects analysis

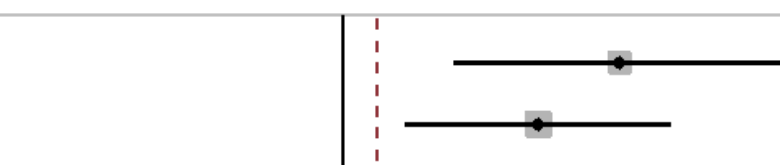

$3.28(1.32,5.23) \quad 2.49$

$2.33(0.75,3.90) \quad 3.56$

$-1.97(-3.91,-0.03) \quad 2.51$

$2.09(0.10,4.09) \quad 2.39$

$0.52(-2.14,3.19) \quad 1.41$

$1.28(-1.14,3.70) \quad 1.69$

$-0.08(-0.39,0.23) \quad 16.75$

$0.24(0.09,0.39) \quad 18.91$

$0.45(-0.09,0.99) \quad 12.92$

$-0.14(-0.66,0.38) \quad 13.20$

$0.41(-0.19,1.01) \quad 11.87$

$1.42(-0.69,3.52) \quad 2.17$

$1.10(-1.46,3.65) \quad 1.54$

$0.51(-0.51,1.52) \quad 6.85$

$0.41(-1.99,2.80) \quad 1.72$

$0.40(0.07,0.73) \quad 100.00$

\section{$-5.23$}

0

Figure 2 
Study

$\%$

ID

LogHR (95\% CI) Weight

Kojima (2000)

Fouladi (2000)

Kim (2003)

Ahn (2003)

Ghavamzadeh (2004)

Yoshida (2014)

Dufour (2015)

Choi (2017)

Cheng (2017)

$\mathrm{Xu}(2018)$

Yang (2019)

Overall $(\mathrm{I}$-squared $=34.7 \%, \mathrm{p}=0.121$ )

NOTE: Weights are from random effects analysis

\section{$-5.23$}

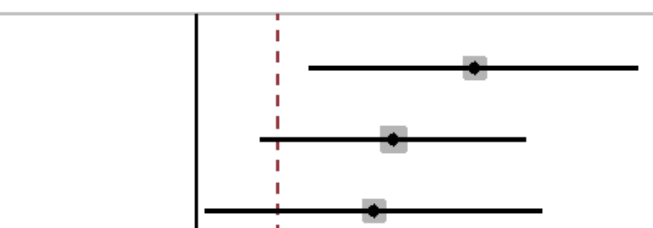

$3.28(1.32,5.23) \quad 5.70$

$2.33(0.75,3.90) 7.97$

$2.09(0.10,4.09) \quad 5.48$

$0.52(-2.14,3.19) 3.31$

$1.28(-1.14,3.70) 3.94$

$0.45(-0.09,0.99) 24.10$

$0.41(-0.19,1.01) 22.56$

$1.42(-0.69,3.52) 5.01$

$1.10(-1.46,3.65) 3.59$

$0.51(-0.51,1.52) 14.33$

$0.41(-1.99,2.80) 4.02$

$0.96(0.44,1.47) \quad 100.00$

\section{Figure 3}


Study

ID

Yoshida (2014)

Choi (2017)

Cheng (2017)

$\mathrm{Xu}(2018)$

Yang (2019)

Overall (I-squared $=0.0 \%, \mathrm{p}=0.690)$
$\operatorname{LogHR}(95 \% \mathrm{CI})$ Weight

$1.66(0.86,2.46) \quad 43.89$

$3.11(1.36,4.87) \quad 9.19$

$1.97(0.51,3.43) \quad 13.33$

$2.10(0.85,3.36) \quad 17.98$

$1.96(0.61,3.31) \quad 15.60$

$1.96(1.43,2.49) \quad 100.00$

Figure 4 
Study

ID

Kojima (2000)

Fouladi (2000)

Ellis (2002)

Kim (2003)

Ahn (2003)

Ghavamzadeh (2004)

Viollier (2005)

Locasciulli (2007)

Cheng (2017)

$\mathrm{Xu}$ (2018)

Overall (I-squared $=57.1 \%, \mathrm{p}=0.013$ )

NOTE: Weights are from random effects analysis

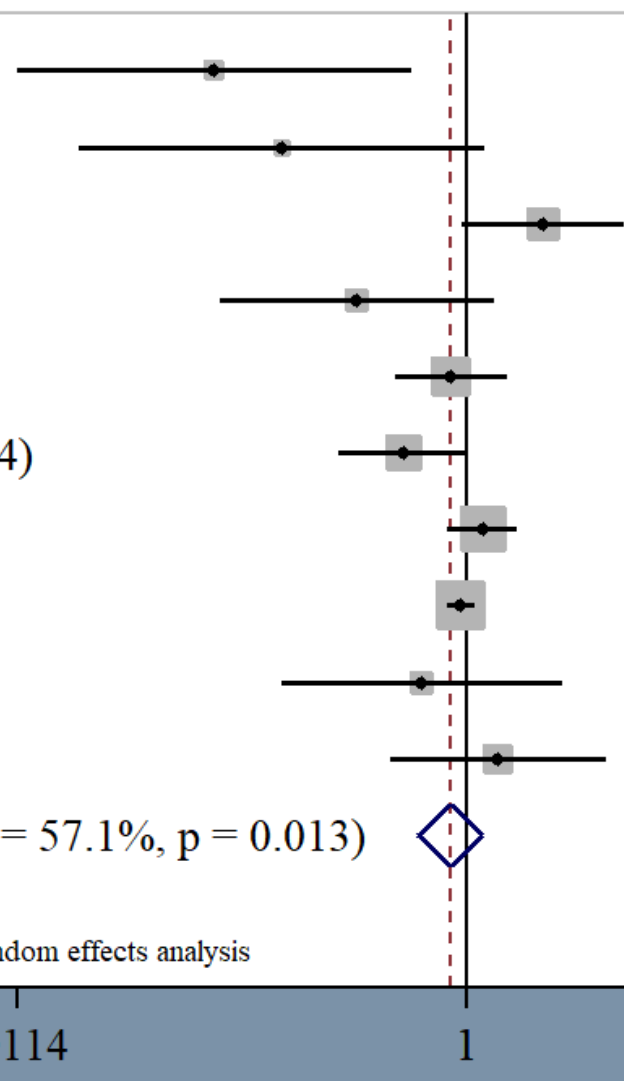

$0.08(0.01,0.58) 2.42$

$0.16(0.02,1.20) 2.29$

$2.13(0.95,4.80) 9.68$

$0.34(0.09,1.33) 4.50$

$0.86(0.49,1.50) 14.25$

$0.53(0.28,1.01) 12.61$

$1.17(0.82,1.67) 19.32$

$0.95(0.82,1.09) 23.98$

$0.64(0.16,2.59) 4.39$

$1.38(0.47,4.03) 6.58$

$0.85(0.62,1.17) 100.00$

\section{Figure 5}

